\title{
ALFONSO CASO ANDRADE, 1896-1971
}

IN THE MIDST of a large family, Alfonso Caso was born on 1 February 1896. A brilliant student from his early years, a quality he maintained until his death, by 1919 he had a degree in law and a year later a master's in philosophy, both from the National University of Mexico. There he taught logic and epistemology from 1918 to 1940, and law until 1929. Up to 1930, he held a number of positions both in the university and the federal government. Today these appear as only a prelude to the more important posts he would hold in later years.

It was only towards 1926 that Caso became interested in archaeology. He himself said, probably synthesizing at one moment what must have been a long mental and affective process, that after an expedition to Xochicalco he decided he wanted to know what those hieroglyphs meant and what those ruins stood for. He began reading on his own and taking a few courses, mainly with Herman Beyer, and soon realized that with the knowledge available at that time he would never be able to read the engravings on those mute monuments. It is rather sad to think that after 45 years of work and after becoming the greatest authority on glyphic inscriptions in central Mexico, he could never decipher those inscriptions nor the Monte Albán stelae, which were the first objects of his serious endeavors.

During the 1930's, Caso was director of the National Museum, at that time called Museum of Archaeology, History, and Ethnology, but his great step forward occurred in 1939 when he founded the I.N.A.H. (Instituto Nacional de Antropologia y Historia), and together with it the School of Anthropology. This is where I met him for the first time in 1941, as a student in his brilliant course on the archaeology of Mexico. Actually it was entirely his fault that at the end of the year, after going with him to Monte Alban, I decided to embark on this rather unprofitable career on a professional basis. Caso was certainly one of the most extraordinary professors I have ever known and perhaps the only criticism that can be laid to his teaching is that his clarity of mind and his perfect exposition made all problems seem easy and practically solved.

Many people have spoken of his classes in philosophy and law, which unfortunately I did not follow. One of his students, Agustín Yañez-who was later to become Secretary of Educationwrote of him in those years:

I was impressed by the assurance of his figure, of his movements, and above all by the inflection of his voice, which left no room for discussion. The first impression-almost only a feeling-was followed or was perhaps simultaneous with an impression of absolute clarity.

This is exactly what I thought of him during the years I attended his classes at the School of Anthropology and during the numerous lectures I had the good fortune to hear him give. Such a nervous impatient man, he was always willing to impart his knowledge to anybody, no matter how ignorant, so long as he saw genuine interest in the subject. If he discovered that there was only brass under the apparent gold, however, he would stop and forever afterwards forget the presumptuous ignoramus, and this was final because his extraordinary memory rarely allowed him to forget anything, whether it was in archaeology or in life. I believe it is practically impossible for anybody who has only read his books to appreciate the remarkable precision of his intellect and the sharpness of his wit. He gave the impression of a perfectly ordered machine. Discoursing, he actually seemed like reason incarnate.

This is not the moment to include a complete bibliography of Caso. I shall just try to mention the principal subjects that occupied his attention as an archaeologist. Probably the most important one, and his first love, was the study of prehispanic writing. Thus, apart from lithic inscriptions, the codices were obviously his main source. During $40 \mathrm{yr}$ he continued this terrific work and went into fields of inquiry where nobody could show him the way, and if his success could not be total, he certainly obtained the triumph of deciphering in large part the forgotten writing and of reviving a forgotten world. His last book-Kings and Kingdoms of the Mixteca-was entirely finished a few days before his death and will appear as soon as possible. It contains a whole dynastic history and a wealth of glyphic material that will certainly open the road to more total research in this field. He found the key to Mixtec history in a document-apparently of secondary 
importance--that he published in 1949 under the title of El mapa de Teozacoalco. No matter how small this paper may seem, from it developed the great work that was to culminate in The Kings and Kingdoms of the Mixteca.

It is obviously impossible to do this type of research without some understanding not only of the prehispanic calendars but of the synchronology between them and the Christian one, and so he also went fully into this subject. Already on 19 May 1938 he gave a famous talk at the Sociedad Mexicana de Antropologia establishing a new correlation between the Aztec and the Christian calendars. A lot more work was to be done and most of it is covered in the volume Los calendarios prehispánicos (1967). This necessarily led to yet a third subject of inquiry, prehispanic religion. However much he separated himself from Seler's ideas in the question of historical meaning for some of the pictographic documents, Caso always considered the old master as a source in his study of prehispanic religion. Apart from a few minor publications, Caso's main work on the subject was El pueblo del sol, published in 1953 and later translated into English.

This very brief summary of Caso's major activities must include those at his favorite site, Monte Albán. By 1929 he had published Las estelas zapotecas, and-unhappy about the lack of dating or any known chronology-he started excavations at this site in the winter of 1930 . These were to last for $20 \mathrm{yr}$, although Caso was not present in the last field seasons. He continued digging there even when he was President of the National University of Mexico and while he was in the Cabinet of President Miguel Alemán. The magnificent results obtained, although many are still unpublished, led to a number of partial reports and to 3 large volumes: Urnas de Oaxaca (1952); La cerámica de Monte Albán (1967), and El tesoro de Monte Albán (1969).

I believe Caso knew every stone that had appeared, every tomb, and every pot that he uncovered at Monte Albán. It might be easy to criticize today some of the field methods he followed, but when he started digging in 1930 he practically had to invent his own field manual. His field notes from that period are so thorough and so intelligently phrased that one can still understand them with great ease and recover all the information in the particular field that interested him. Those were not the days of ecology and of settlement patterns, but the days in which archaeology in Mexico was dedicated to the excavation and restoration of major monuments. This he did at Monte Albán so perfectly that no changes have been necessary there in more than $30 \mathrm{yr}$, and he succeeded in recovering for us, without the least bias to truth, one of the most beautiful sites in the Americas.

Caso was always interested in art, and his thesis to obtain his degree in philosophy was entitled "An Essay for a New Classification of the Arts." Perhaps this is what gave him the extraordinary vision that could discern on a battered stone or in a torn document things which simply did not exist for a less learned viewer; but in every instance it was not a question of romantic imagination but of phenomenal insight into the figures, and every time he could prove his opinion.

From 1949 (when he founded it) until the day of his death, Alfonso Caso was director of the I.N.I. (Instituto Nacional Indigenist). He approached this formidable task with all the enthusiasm and competence that he put into everything. Against enormous difficulties, he managed to create and to make function a number of centers in many different Indian areas, and he had plans for many more which for economic reasons he could not realize. The whole institution and the work in these centers clearly reflect Caso's philosophy on the Indian problem and his constant effort to raise the living standards and, finally, to incorporate the Indian groups within the national culture.

During his lifetime, Caso received innumerable honors, but most important, on 30 November 1970 when he died, was the lasting impression he left on all his friends. We shall never forget the man himself, his personality, his intelligence, and his goodness. For many years back he considered himself a nonbeliever, which he was, but if he had lost his faith he had retained all the essential Christian qualities that he learned as a child. Like few others, he understood the significance and the dignity of being a man, and as a man he accepted the honors and the triumphs and the joys, but also the hardships of life. 